\title{
A CASE OF PRIMARY IDIOPATHIC HYPOGAMMAGLOBULINAEMIA ASSOCIATED WITH HAEMOLYTIC ANAEMIA
}

\author{
Eileen N. Thompson, M.B., B.S. \\ Medical Registrar
}

R. Sleigh Johnson, M.D., M.R.C.P. Consultant Physician
DEFICIENCY in the gamma globulin content of the blood may be a congenital, and usually familial, abnormality, or acquired, and of the latter group some cases are primary or idiopathic, without demonstrable cause, while others are secondary to a known disease, especially one affecting the blood or reticulo-endothelial system. The case now described shows features of the primary acquired type, but with the rare accompaniment of a hæmolytic anæmia.

\section{Case Report}

A woman, aged 5I years, first seen in April 1959. gave a history of four years' recurrent upper respiratory infections and two episodes of erysipelas, all responding slowly to prolonged antibiotic therapy. Her previous health had been good and the family history unrelated. Two months before attending she had developed a severe bilateral patchy bronchopneumonia, which responded only slightly and temporarily to antibiotics. A mild hypochromic anæmia with $71 \%$ hæmoglobin and normal leucocyte count was present at this time, but no biochemical investigations of the blood were then made. Despite a gradual lessening of symptoms and consolidation, fatigue and malaise persisted, with an early relapse of productive cough.

In September 1959 she was admitted to hospital extremely ill from an exacerbation of chest infection, preceded for a month by intermittent pyrexia with rigors, cough and abundant creamy purulent sputum. She was thin, sallow and dyspnoic, with pale mucous membranes and finger clubbing, and showed clinical signs of extensive pneumonia. X-ray examination confirmed a soft patchy consolidation involving all lobes, with probable early cavitation in both lower lobes (Fig. I). Sputum examination was repeatedly negative for tubercle bacilli and fungus infection and showed a growth of penicillinresistant $H$. influenze and streptococcus pneumonia. She was further noted on admission to have a firm enlargement of the liver $I$ in. and of the spleen $I \frac{1}{2}$ in. below the costal margin, with small discrete glands palpable in the neck, axillæ and groins. Apart from the above findings, clinical examination was negative.

Despite frequent changes of antibiotics, six in all, clinical improvement was slight and temporary and the radiological changes those of steady deterioration. Bronchiectatic cavitation increased, with secondary interstitial changes widely throughout the lung fields. In view of the repeated and resistant respiratory infections, in conjunction with the hepato-splenomegaly, the

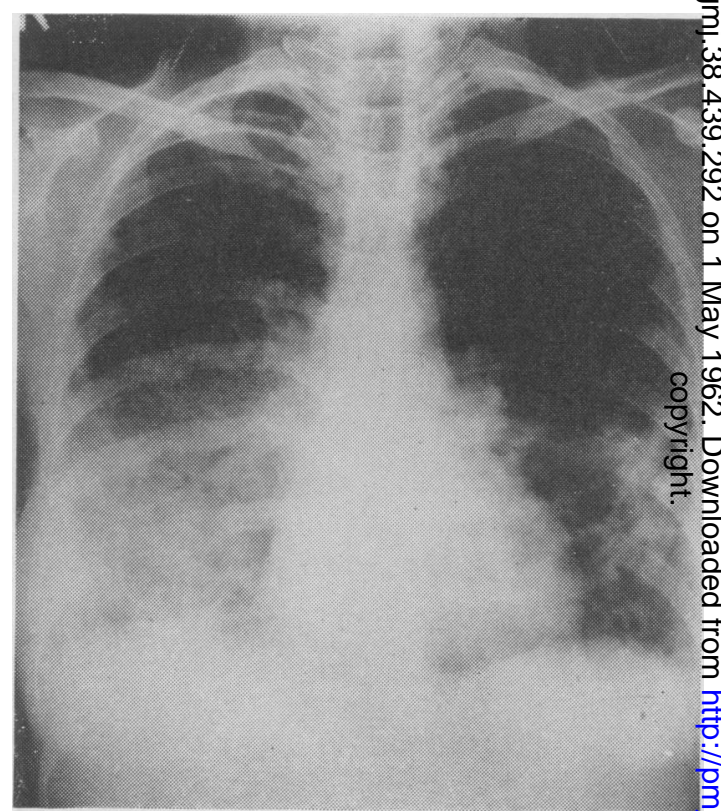

FIG. 1.-Postero-anterior X-ray film of chest, 29.9.59: showing widespread patchy broncho-pneumonie consolidation.

possibility of hypogammaglobulinæmia was considered and appropriate investigations made for this and related states.

\section{Investigations}

Initial blood count: $\mathrm{Hb} 67 \%$, r.b.c. $3,360,000 / \mathrm{cmm}$ normal appearance, with $4 \%$ of reticulocytes and normaR blood platelets; w.b.c. 9,000/c.mm, $86 \%$ polymorphs $14 \%$ lymphocytes. E.S.R. (Westergren) $100 \mathrm{~mm}$./hour Blood urea normal; urine, only a trace of albumini liver function tests normal. Daily fæcal fat excretion an average of $2.2 \mathrm{~g}$. over a five days' observation excluding a steatorrhœa. Needle-biopsy of the liver, no abnormality; that of the sternal marrow showed ano over-active erythropoiesis with marked increase o $\overline{\bar{O}}$ normoblast cells and slight iron deficiency; leuco $\widetilde{\Phi}$ poiesis appeared normal and no plasma cells were seen.? 


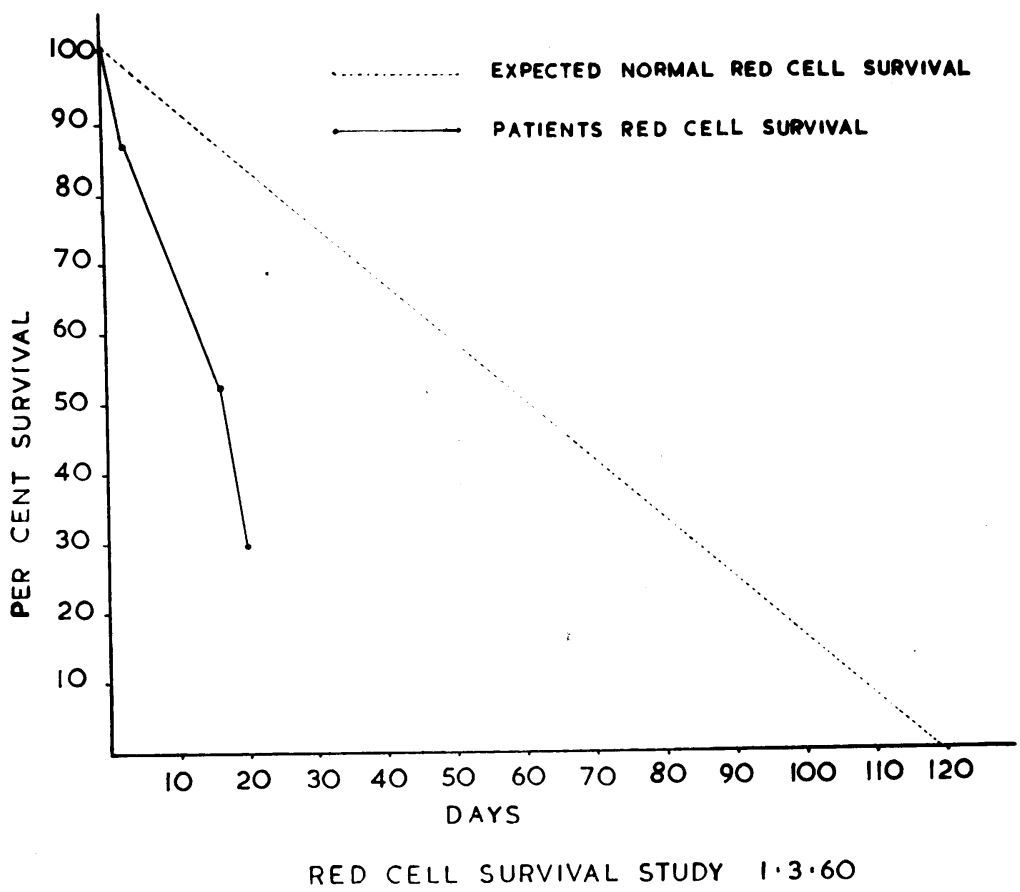

FIG. 2.-Red-cell survival time estimation, 1.3.60, showing increased rate of destruction of transfused red blood cells.

The total serum protein content was low, $4.5 \mathrm{~g} . / 100$ $\mathrm{ml}$, with $2.8 \mathrm{~g}$. $/ 100 \mathrm{ml}$. albumin and $1.7 \mathrm{~g} . / 100 \mathrm{ml}$. globulin. Paper electrophoresis showed a marked deficiency of gammaglobulin, quantitative estimates suggesting that this was less than $0.4 \mathrm{~g} . / 100 \mathrm{ml}$. This was confirmed by a salt-precipitation method (Wolfson, Cohn, Calvary and Thomas, I948), which gave a result of $0.2 \mathrm{~g}$. gammaglobulin per $100 \mathrm{ml}$. (normal 0.7 to $\mathbf{1 . 2}$ g. $/ 100 \mathrm{ml}$.). Neither of these methods gives an accurate quantitative result at low levels, but Dr. J. F. Soothill, using a specific immunochemical method, found in this patient a gammaglobulin level of only $60 \mathrm{mg} . / 100 \mathrm{ml}$, so proving the diagnosis of hypogammaglobulinæmia. Biopsy of an enlarged axillary gland showed a marked follicular hyperplasia, but no evidence of reticulosis. Mature plasma cells, thought to be responsible for the production of gammaglobulin, were not seen (Dr. K. A. D. Turk).

Other tests were made to determine any related deficiency of circulatory antibodies and impaired immunological response. The patient's blood group was A II Rhesus-negative, but no iso-agglutinins were present in undiluted serum. The Mantoux reaction ( 1 in 1,000 dilution) had been positive in 1954 , but was now negative at $I$ in 100 dilution. The Widal reaction was negative. After injection of $1.25 \mathrm{ml}$. of T.A.B. vaccine there was a transient rise in the Salmonella typhi H. titre of $I$ in 160 , but two weeks later all titres of the test were less than $I$ in 10 . The Schick test was positive before and after the giving of $\mathrm{I}$ ml. of T.A.F.

During these investigations a persistent rise of the reticulocyte count to between $4 \%$ and $6 \%$ was observed, and from the lack of evident blood loss and the splenic enlargement present this was suspected to be due to intravascular hæmolysis, with resultant anæmia. The direct Coombs' test, however, was negative and the osmotic fragility of the red blood cells was normal, while no rise was found in the serum-bilirubin content (less than $0.5 \mathrm{mg}$./100 ml.), nor any excess of urobilin or hæmosiderin in the urine. As a more exact index of hæmolysis, an estimation of the red cell survival time was therefore made, using cells of a different, but compatible, blood group. This test showed definite evidence of an increased rate of destruction of the transfused cells (Fig. 2). The continuance of this hæmolysis was confirmed six months later, using a radioactive chromiumlabelled red cell technique, by means of which the mean red-cell life in this patient was then shown to be approximately half of the normal red-cell span. Confirmatory results were given also by an estimation of the fæcal stercobilin excretion, which showed an increase to $26 \mathrm{mg}$. $/ 24$ hours/100 g. of circulating hæmoglobin (normal maximum stated to be $22 \mathrm{mg} . / 24$ hours/100 g.), and of the serum haptoglobin, which was reduced to $30 \mathrm{mg}$. $/ 100 \mathrm{ml}$. (normal 50 to $140 \mathrm{mg} / \mathrm{I} 00 \mathrm{ml}$.); each of these findings by the methods used being held to indicate the presence of intravascular hæmolysis.

The diagnosis of hypogammaglobulinæmia, indicated by the extremely low content of this fraction in the plasma proteins, was thus supported by an absence of iso-agglutinins and a typical lack of immunological response to the standard dose of T.A.B. and of diphtheria toxin. In this patient's case a congenital form of the disease seemed excluded by the absence of illness in childhood. Other conditions known to be associated with a secondary hypogammaglobulinæmia, including myelomatosis, chronic lymphatic leukæmia, nephrosis, amyloidosis, rheumatoid arthritis and reticulosis, were excluded, and the condition in this patient therefore regarded as a primary acquired form of the disease. The four remaining siblings in the family were also investigated; in none was any abnormality detected on clinical examination or on plasma protein analysis and electrophoresis.

\section{Response to Treatment}

As customarily found, at no time did antibiotic therapy on orthodox lines produce more than an in- 


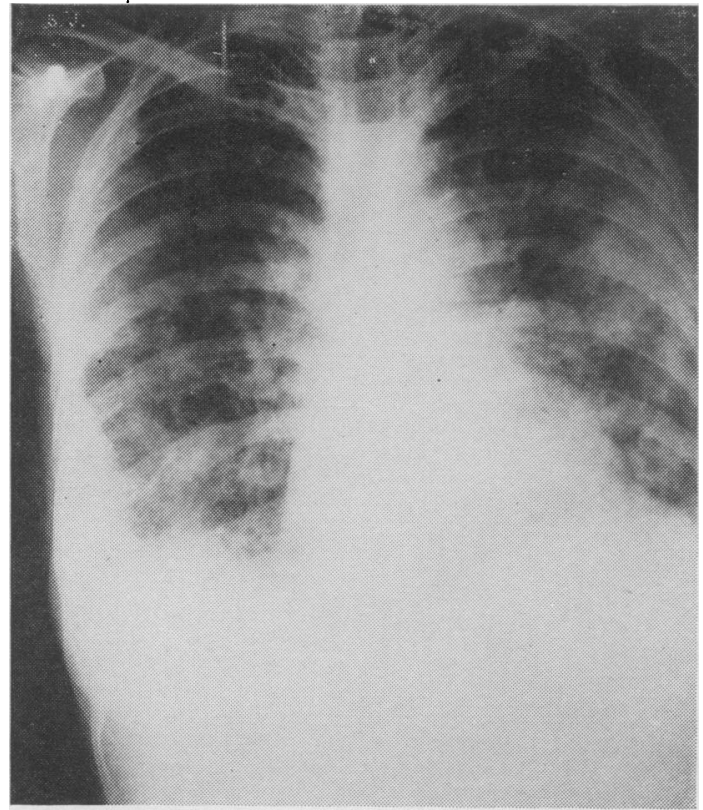

FIG. 3.-Postero-anterior X-ray film of chest, 4.I I.59, showing failure of response of broncho-pneumonic infection to intensive antibiotic therapy.

complete and transient improvement, either clinically or radiologically (Fig. 3). Treatment with gammaglobulin was therefore considered, and as the criteria of suitability under the Medical Research Council's Trial Scheme were satisfied, including a fractional serum content of $0.2 \mathrm{~g} . / 100 \mathrm{ml}$. or less, she was accepted for treatment. This was begun on 30.1 1.59, giving after loading doses an average of $0.025 \mathrm{~g} . / \mathrm{kg}$. body weight by weekly intramuscular injection for the first year, to be followed by double this amount during the second year. Subsequent periodic blood sampling during this treatment showed a rise of serum gammaglobulin content from the initial $60 \mathrm{mg} . / 100 \mathrm{ml}$. up to a maximum of $560 \mathrm{mg} . / 100 \mathrm{ml}$. (Dr. J. F. Soothill). The clinical response in respect of the infections was impressive. Without prophylactic antibiotics the patient remained free from any infective incident for a period of 14 months, while the pneumonic process resolved (Fig. 4), with gain of weight and appetite and ability to resume work. There was subsequently a mild intercurrent upper respiratory infection during an influenzal epidemic with some scattered bronchitic signs, which responded quickly to antibiotics and was not associated with any clinical or radiological recurrence of pulmonary consolidation; following this incident she has remained well to the present date over a further ro months, with gain in weight and freedom from cough and sputum. Weekly injections of gammaglobulin, $2.56 \mathrm{~g}$., have been maintained throughout, but after the occasional use of tetracycline in small dosage no antibiotic drugs have been required during the last three months of this period, the chest remaining clear of abnormal signs.

\section{Discussion}

While the diagnosis of hypogammaglobulinæmia in this patient appears proven, the unusual feature has been the presence of hæmolysis. In a review

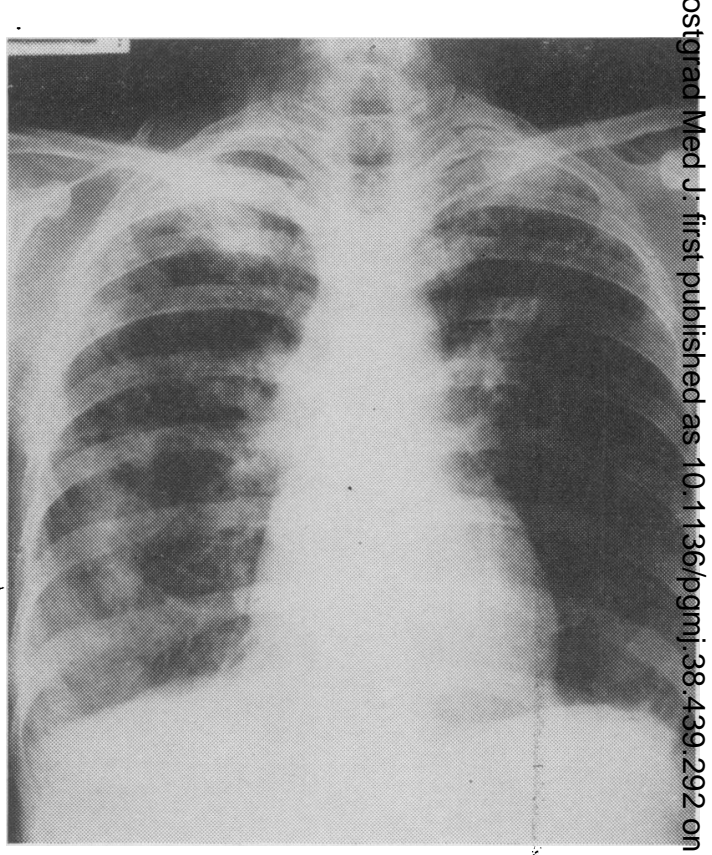

Fig. 4.-Postero-anterior X-ray film of chest, 23.3.6\%, showing resolution of pneumonic changes aft treatment with intramuscular gammaglobulin.

by Citron (1957) of the medical literature, out of reported cases of hypogammaglobulinæmia 2 six

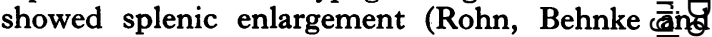
Bond, 1954; Grant and Wallace, 1954; Rose Trobaugh and Danforth, I955; Collins and Dudle 1955; Young, Wolfson and Cohn, 1955; Good ant Mazzitello, 1956). All six were of the acquireil idiopathic type of the condition. Of these six cases with splenomegaly, three showed a neutropenia with lack of neutrophil response during the infections, and three had an acquired hæmolytic anæmiă in two of the latter patients splenectomy was pe? formed with relief of the anæmia in each case. Further instances of associated hypersplenism and hæmolytic anæmia in the acquired type of gamm globulin deficiency have been published by PrasaA and Koza (1954, the first case described), Prasa $\&$, Reiner and Watson (1957, one additional case) and by Standaert and De Moor (1955), Martin, Gordan and McCullough (1956), and Brï ckel, Neuffer and Frankel (1956) (each a single case), this seris likewise including two patients subjected splenectomy, with recovery in one and death frofis bronchopneumonia in the second. A total of eight cases of hypogammaglobulinæmia with hæmolytie anæmia has thus been traced in the medical literature.

A reasonable explanation of the development hæmolytic anæmia and neutropenia in these case and of their relief by splenectomy, is the hypothesifs of a secondary hypersplenism, with destruction of erythrocytes, leucocytes or both by the enlarges spleen. In none of the cases recorded was anify other specific cause found for the splenomegal 
and it was postulated that a compensatory reactive hyperplasia of the reticulo-endothelial system had occurred, with hyperphagocytosis, as a result of repeated infections due to the almost complete lack of gammaglobulin and deficiency or absence of circulating antibodies.

In the patient at present described it seems probable that the pathology is of the same nature, with hæmolysis a direct result of hypersplenism, the splenic enlargement having now reached nearly to the umbilical level. An alternative cause of the hæmolysis as due to a specific antibody formation seems unlikely, in that the patient showed no demonstrable antibody response in the provocative tests employed. Supporting evidence of hypersplenism was given by the absence of leucocytosis throughout the course of illness, the white cell count never being higher than $10,000 /$ c.mm. at the height of the severe pulmonary infection. The platelet count was unaltered. The sedimentation rate was persistently raised, being from Ioo to I $10 \mathrm{~mm}$. in one hour (Westergren) at the height of the pulmonary infection, and between 24 and 40 $\mathrm{mm}$. subsequently. This was an unusual finding, although present in some recorded cases, the levels in this condition being more commonly low during the infective episodes, in conformity with the known association between the sedimentation rate and the plasma globulins.
During treatment with gammaglobulin, despite a fall in the reticulocyte count to $2 \%$, with rise of hæmoglobin to $85 \%$ and serum haptoglobin to $90 \mathrm{mg} . / 100 \mathrm{ml}$., the fæcal stercobilinogen excretion was still found to be increased, and the survival time of transfused red cells became further shortened, so that it must therefore be concluded that abnormal hæmolysis is still continuing. It is not yet known whether with more prolonged control of the infective episodes by gammaglobulin therapy the hypersplenism will be abated. Should this not follow and a relapse of anæmia develop, the possible need for splenectomy must then be considered.

\section{Summary}

A case is described in which idiopathic hypogammaglobulinæmia was associated with hæmolytic anæmia. The evidence for this combined diagnosis is presented and its implications discussed.

We wish to express our acknowledgments and thanks to the Medical Research Council for supplies of gammaglobulin for use in treatment of this patient, to Dr. J. F. Soothill for estimations of serum-gammaglobulin, to Mr. P. M. G. Broughton for many biochemical investigations and to the Radiotherapy Department of the North Middlesex Hospital for red-cell survival rate estimations.

\title{
REFERENCES
}

Brückel, K. W., Neuffer, P., and Frankel, F. H. (1956): Gammaglobulin Mangel Syndrome und Humorale Abwehre unter besonderer Berücksichtigung der Agammaglobulinamie, Klin. Wschr., 34, 304.

Citron, K. M. (1957): Agammaglobulinæmia with Splenomegaly, Brit. med. F., i, i 148.

Collins, H. D., and Dudley, W. R. (1955): Agammaglobulinæmia and Bronchiectasis: Two Cases in Adults, New Engl. F. Med., 252, 255.

Good, R. A., and MAzzitello, W. F. (1956): Chest Disease in Patients with Agammaglobulinæmia, Dis. Chest, 29, 9.

Grant, G. H., and Wallace, W. D. (1954): Agammaglobulinæmia, Lancet, ii, 671 .

Martin, C. M., Gordon, R. S., and MCCullough, N. B. (1956): Acquired Hypogammaglobulinæmia in an Adult, New Engl. F. Med., 254, 449.

Prasad, A. S., and KozA, D. W. (1954): Agammaglobulinæmia, Ann. intern. Med., 41, 629.

- REINER, E., and WATSON, C. J. (1957): Syndrome of Hypogammaglobulinæmia, Splenomegaly and Hypersplenism, Blood, 12, 926 .

Rohn, R. J., BeHNKe, R. H., and Bond, W. H. (1954): Acquired Agammaglobulinæmia with Hypersplenism, F. Lab. clin. Med., 44, 918.

Rosecan, M., Trobaugh, F. E., and Danforth, W. H. (1955): Agammaglobulinæmia in the Adult, Amer. F. Med., 19, 303 .

StANDAERT, L., and De Moor, P. (1955): L'Agammaglobulinæmia chez L'Adulte, Acta clin. belg., ro, 477.

Wolfson, W. Q., Cohn, C., Calvary, E., and Thomas, E. N. (1948): Studies in Serum Proteins, $\mathcal{~}$. Lab. clin. Med., $33,1276$.

Young, I. I., Wolfson, W. Q., and Cohn, C. (1955): Studies in Serum Proteins, Amer. F. Med., 19, 222.

\section{A CASE OF ACUTE ILEITIS WITH PERFORATION}

\author{
J. B. L. TAYloR, F.R.C.S. \\ Surgical Registrar, Stockport Infirmary
}

ACUTE ILEITIS is uncommon in surgical practice and some doubt exists about its pathology and natural history. A case report of acute ileitis with perforation in a child is presented.

\section{Case Report}

The patient, a boy aged ro, was admitted to hospital on 8.9.59 with a diagnosis of acute appendicitis. $\mathrm{He}$ gave a history of colicky lower abdominal pain of 36 hours' duration. He had vomited several times and had some diarrhcea, the motions being loose, but not containing blood. On examination there was tenderness and rigidity in the right iliac fossa. The temperature and pulse were normal. 